(Received March 3, 1982)

\title{
RATES OF DYEING OF NYLON WITH ORANGE II IN THE PRESENCE OF SODIUM ALKYLSULFATES
}

\author{
By Masaru Mitsuishi, Daisuke Yoshida, Hisao Maruyama, \\ and Tsutomu Ishiwatari
}

(Faculty of Textile Science and Technology, Shinshu University, Tokida, Ueda-shi, Nagano-ken, 386)

\begin{abstract}
The time-adsorption curves were obtained for the dyeing of nylon with Orange II in the presence of sodium $n$-alkylsulfates (SAS), such as octyl, decyl, dodecyl, tetradecyl, and hexadecylsulfates at $90^{\circ} \mathrm{C}$. The curves obtained in the absence and the presence of SAS's (except SHS) were found to be represented by $M_{t}=M_{i}\left(1-e^{-k t}\right)$, where $M_{t}$ and $M_{i}$ refer to the amounts of the dye taken up by nylon at time $t$ and at equilibrium, respectively, and $k$ refers to the rate constant. The curve obtained in the presence of SHS had an adsorption maximum at about $t=6 \mathrm{~min}$. The values of $M_{i}$ 's and $M_{t}$ 's decreased with an increase of the concentration of SAS's, which was especially prominent in the case when SAS's had higher affinities for nylon. The rate constant obtained in the presence of SAS's were found to be smaller than that obtained in the absence of SAS. The diffusion coefficients in the presence of SAS's (except STS) were also smaller than that in the absence of SAS.
\end{abstract}

Anionic surface active agents have been extensively used for the level dyeing of polyamide fiber with acid dyes, ${ }^{1)}$ because they slow down the rate of dyeing by their affinity to the positively charged sites on nylon in competition with dye anion. In fact, dodecylsulfate is known to decrease the equilibrium dye adsorption of several kinds of acid dyes, especially of those with relatively low affinities for nylon. ${ }^{2,3)}$ However, there have been few reports on the effects of such anionic surface active agents on the rates of acid dyeing of nylon.

The present paper reports the rates of dyeing of nylon with Orange II in a stirred solution of limited volume in the presence of five kinds of sodium $n$-alkylsulfates.

\section{Experimental}

Nylon-6 (diameter: $17.2 \mu \mathrm{m}$, amino end group:
$5.35 \times 10^{-5} \mathrm{eq} / \mathrm{g}$ ) and Orange II (C.I. Acid Orange 7) used in this experiment were described in the previous paper." Sodium $n$-alkylsulfates (SAS) used were sodium octyl, decyl, dodecyl, tetradecyl, and hexadecylsulfates. The abbreviations of SAS's and the affinities of SAS's for nylon at $90^{\circ} \mathrm{C}$ are shown in Table 1 . The SAS's were prepared by the method described in the previous paper. ${ }^{4)}$

Measurements of the rates of dyeing of nylon with Orange II were carried out as follows. $3.0 \mathrm{mg}$ of nylon fiber was dyed in $3.00 \mathrm{ml}$ dye solution $(\mathrm{pH}=3.0)$ in the spectrophotometric cell equipped with a magnetic stirrer ( 400 r.p.m.) and thermostatted at $90^{\circ} \mathrm{C}$. The change of the absorbance of the dye solution at the absorption maximum $(495 \mathrm{~nm})$ was recorded automatically at 30 second intervals. The amounts of Orange II taken up by

Table 1 Dye and Sodium $n$-alkylsulfates

\begin{tabular}{l|c}
\hline Dye and Sodium $n$-Alkylsulfates & Affinity of Free Acid for Nylon \\
\hline Orange II (C.I. Acid Orange 7) & $14.8 \mathrm{kcal} / \mathrm{mol}$ \\
sodium $n$-octylsulfate (SOS) & 14.4 \\
sodium $n$-decylsulfate (SDS) & 14.6 \\
sodium $n$-dodecylsulfate (SLS) & 14.7 \\
sodium $n$-tetradecylsulfate (STS) & 14.9 \\
sodium $n$-hexadecylsulfate (SHS) & 15.2 \\
\hline
\end{tabular}


nylon were determined in the ordinary way.

\section{Results and Discussion}

\section{Rates of Dyeing of Nylon with Orange II}

The time-adsorption isotherms of Orange II dyeing of nylon in the absence and the presence of $5 \times 10^{-5} \mathrm{M}$ SAS's at $90^{\circ} \mathrm{C}$ are shown in Fig. 1 . The isotherms in the presence of various concentrations of SLS at $90^{\circ} \mathrm{C}$ are shown in Fig. 2. Figs. 1 and 2 show that the amounts of Orange II taken up by nylon are less in the presence of SAS's than in the absence of SAS. Fig. 1 shows that the more the carbon atoms in the alkyl group of SAS's (i.e., the higher the affinities of SAS's for nylon), the less the amount of Orange II taken up by nylon. Fig. 2 indicates that the amount of Orange II taken up by nylon apparently decrease with an increase in the concentrations of SLS in the bath. In the presence of SHS the time-adsorption isotherm shows an adsorption maximum at about $t=6 \mathrm{~min}$. This finding is qualitatively interpreted as follows. The affinity of Orange II for nylon is smaller than that of SHS, Orange II diffuses first into nylon substrate, and then is adsorbed on the sites of nylon ahead of SHS. SHS diffuses afterward into nylon, and desorbs the dyes from the sites due to the higher affinity.

The decrease of the amounts of Orange II uptake in the presence of SAS's may be explained as follows. The amoúnts of the dye and SAS $\left(M_{D}\right.$ and $M_{S}$ ) taken up by nylon at time $t$ are controlled by their diffusion coefficients $\left(D_{D}^{\circ}\right.$ and $\left.D_{S}^{\circ}\right)$ and their affinities $\left(-\Delta \mu_{D}^{\circ}\right.$ and $\left.-\Delta \mu_{S}^{\circ}\right)$ and concentrations in the bath $\left((D)_{B}\right.$ and $\left.(S)_{B}\right)$, as approximately represented by Eq. $\left.1,{ }^{5}\right)$

$$
\frac{M_{D}}{M_{S}}=\frac{D_{D}^{\circ}}{D_{S}^{\circ}} \frac{z_{D}}{z_{S}} \frac{(D)_{B}}{(S)_{B}} \exp -\left(\Delta \mu_{D}^{\circ}-\Delta \mu_{S}^{\circ}\right) / R T
$$

where $z_{D}$ and $z_{S}$ refer to the basisities of the dye and SAS, respectively.

Assuming that the diffusion coefficient of the dye is comparable to that of SAS, Eq. 1 shows that the up-take of Orange II $\left(M_{D}\right)$ decrease with an increase in the affinities or in the concentration of SAS's in the bath.

The rate constant of Orange II dyeing can be estimated by fitting an empirical equation to the time-adsorption curve. One of the most commonlyused equations is the exponential formula given

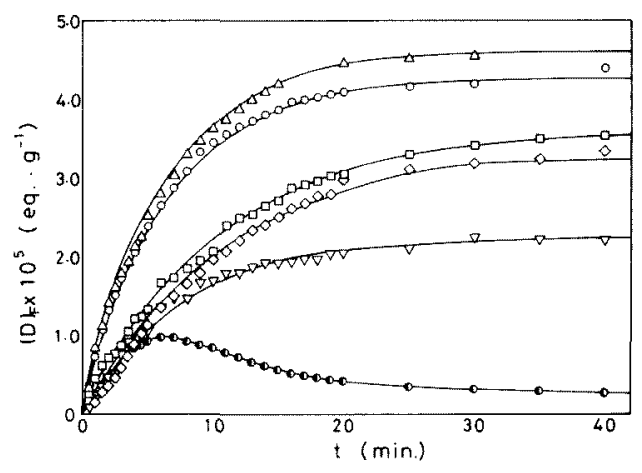

Fig. 1 Time-adsorption isotherms of Orange II dyeing of nylon in the absence and presence of sodium $n$-alkylsulfates

$\triangle$ in the absence of SAS

$O$ in the presence of $5 \times 10^{-5} \mathrm{M}$ SOS

․ SDS

, SLS

$\nabla \quad$ STS

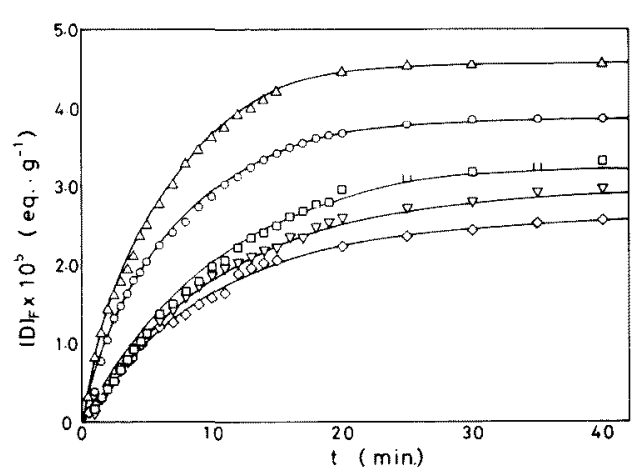

Fig. 2 Time-adsorption isotherms of Orange II dyeing of nylon in the presence of sodium $n$-dodecylsulfate

$\triangle$ in the absence of SLS

0 in the presence of $3 \times 10^{-5} \mathrm{M}$ SLS

$\begin{array}{lll}\square & \text { ". } & 5 \\ \nabla & \text { ". } & 7.5 \\ \diamond & . & 1.0 \times 10^{-4}\end{array}$

by ${ }^{6)}$

$$
M_{t}=M_{i}\left(1-e^{-k t}\right)
$$

where $M_{i}$ refers to the amount of the dye taken up by nylon at equilibrium, $k$ an empirical rate constant.

$M_{i}$ and $k$ values were obtained from the timeadsorption curves in Figs. 1 and 2, and they are 
given in Table 2. The solid lines in Figs. 1 and 2 except for the one for SHS, indicate the isotherms calculated by Eq. 2, which reproduce quite satisfactorily the experimental results. Table 2 indicates that $k$ values are smaller in the presence of SAS's than in the absence.

So-called "half-dyeing time", $t_{1 / 2}$, which is the time required for the fibre to adsorb half as much dye as it will adsorb at equilibrium, is often used as the measure of the rate of dyeing, and it is given by Eq. $3^{7)}$

$$
t_{1 / 2}=\ln 2 / k
$$

Values of $t_{1 / 2}$ are also given in Table 2 .

Thus the addition of SAS's to the bath was found to decrease both the take-up of Orange II and the rate of dyeing. Since the rate of the dyeing is considered to be controlled by the diffusion of the dye into the fibre, we have tried to determine the diffusion coefficient of Orange 11 in nylon.

\section{Diffusion Coefficients of Orange II in Nylon}

The concentration of Orange II in cylindrical nylon filament is a function of radius of the filament, $r$, and time, $t$; the diffusion equation is given by Eq. 4, ${ }^{8}$

$$
\frac{\partial c}{\partial t}=\frac{1}{r} \frac{\partial}{\partial r}\left(r D \frac{\partial c}{\partial r}\right)
$$

where $c$ is the concentration of the dye in nylon, and $D$ is the diffusion coefficient.

When the adsorption of the dye on a cylindrical filament took place in a stirred solution of limited volume through so-called "partition mechanism", Eq. 4 was solved by Wilson.9) Shibusawa's approximate equation $\left.{ }^{10}\right)$, Eq. 5 , to Wilson's is useful in obtaining the diffusion coefficients of Orange II in early stages of the dyeing of nylon in the present work.

$$
M_{t} / M_{i}=\frac{A\left(\frac{D t}{r^{2}}\right)^{1 / 2}-B\left(\frac{D t}{r^{2}}\right)}{1-C\left(\frac{D t}{r^{2}}\right)^{1 / 2}}
$$

where $A, B$, and $C$ are given as follows.

$$
\begin{aligned}
A= & 0.00346\left(\frac{1}{1-E}\right)^{2}+2.28\left(\frac{1}{1-E}\right)-0.061 \\
B= & \text { at } 0.30<E<0.80 \\
& -0.4653\left(\frac{1}{1-E}\right)+2.1754 \\
C= & -0.00628\left(\frac{1}{1-E}\right)^{3}+0.04749\left(\frac{1}{1-E}\right)^{2} \\
& -0.504\left(\frac{1}{1-E}\right)^{2}+0.0924\left(\frac{1}{1-E}\right)^{3}
\end{aligned}
$$

\begin{tabular}{|c|c|c|c|c|c|}
\hline SAS's & $\begin{array}{l}\text { Infinite } \\
\text { Adsorption } \\
\qquad(\text { eq. } / \mathrm{g})\end{array}$ & $\begin{array}{l}\text { Infinite } \\
\text { Exhaustion }\end{array}$ & $\begin{array}{l}\text { Rate } \\
\text { Constant } \\
\left(\min .^{-1}\right)\end{array}$ & $\begin{array}{l}\text { Half- } \\
\text { Dyeing } \\
\text { Time } \\
\text { (min.) }\end{array}$ & $\begin{array}{l}\text { Diffusion } \\
\text { Coefficient } \\
\left(\mathrm{cm}^{2} \min ^{-1}\right)\end{array}$ \\
\hline \multirow{2}{*}{$\begin{array}{l}\text { In Absence of SAS } \\
\text { In Presence of SAS }\end{array}$} & $4.56 \times 10^{-5}$ & 0.543 & 0.169 & 4.1 & $1.01 \pm 0.01 \times 10^{-7}$ \\
\hline & & & & & \\
\hline $5 \times 10^{-5} \mathrm{M}$ SOS & $4.40 \times 10^{-5}$ & 0.542 & 0.154 & 4.5 & $0.92 \pm 0.01$ \\
\hline SDS & 3.63 & 0.436 & 0.095 & 7.3 & $0.68 \pm 0.01$ \\
\hline SLS & 3.36 & 0.423 & 0.095 & 7.3 & $0.64 \pm 0.01$ \\
\hline STS & 2.24 & 0.257 & 0.129 & 5.4 & $1.17 \pm 0.05$ \\
\hline $3 \times 10^{-5} \mathrm{M}$ SLS & 3.86 & 0.485 & 0.148 & 4.7 & $0.99 \pm 0.01$ \\
\hline " & 3.36 & 0.423 & 0.095 & 7.3 & $0.64 \pm 0.01$ \\
\hline 7.5 & 2.98 & 0.378 & 0.092 & 7.5 & $0.73 \pm 0.02$ \\
\hline $1 \times 10^{-4} \mathrm{M}$ & 2.58 & 0.311 & 0.100 & 7.0 & $0.85 \pm 0.03$ \\
\hline
\end{tabular}

$$
\text { at } 0.30<E<0.80
$$

where $E$ is final exhaustion.

When the fraction of the sites on nylon occupied by the dye is small (i.e., in the early stages of dyeing), the requirements for Wilson's expression are approximately fulfilled. So, we estimated the

Table 2 Rates of Orange II Dyeing of Nylon at $90^{\circ} \mathrm{C}$ 
diffusion coefficient of Orange II in nylon in the early stage of dyeing $\left(M_{D} / M_{i} \leqq 0.5\right)$ through Shibusawa's equation. The values are shown in Table 2.

Table 2 shows that the values of the diffusion coefficient of Orange II are reasonably constant, and that the values are smaller in the presence of SAS's than in the absence of SAS except for STS. It is interesting that the diffusion coefficient of Orange II is larger in the presence of STS than in the absence of SAS (STS has the highest affinity for nylon, which higher than that of Orange II).

The present study shows that anionic surface active agents exert sizable influence on the rate of Orange II dyeing of nylon. Small but definite differences between the agents and Orange II are found to be the origin of the rate variation. To advance the study further, details of the dye penetration, e.g., concentration profile as observed by the film roll method, will be helpful. ${ }^{11)}$

The authors would like to express their gratitude to Miss Tomoko Akiyama for her experimental aid.

\section{References}

1) R. H. Peters, Textile Chemistry III, Elsevier Scientific Publishing Ltd., Oxford (1975), p. 874

2) M. Mitsuishi, E. Kosuge and G. Aida, Sen-i Gakkaishi, 21, 23 (1965)

3) M. Mitsuishi, E. Kosuge and G. Aida, ibid, 21, 443 (1965)

4) M. Mitsuishi, T. Ishiwatari, D. Yoshida and S. Takano, ibid, 37, T-108 (1981)

5) E. Atherton, R. H. Peters and D. A. Downey, J.S.D.C., 74, 242 (1958)

6) T. Vickerstaff, The Physical Chemistry of Dyeing, Oliver and Boid, London (1950), p. 137

7) T. Vickerstaff, ibid, p. 135

8) J. Crank, The Mathematics of Diffusion, Clender Press, Oxford (1956), p. 62

9) A. H. Wilson, Phil. Mag., 39, 48 (1948)

10) T. Shibusawa, Sen-i Gakkaishi, 36, P-50 (1980)

11) M. Sekido and K. Matsui, ibid, 20, 778 (1964)

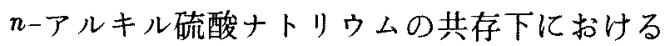

$$
\begin{aligned}
& \text { オレンジII染色速度 }
\end{aligned}
$$

信州大学䋊維学部 三石 留, 声田大介, 丸山尚夫，石渡 勉

\footnotetext{
オクチル，デシル，ドデシル，テトラデシル(STS), およびへキサデシル硫酸ナトリウム(SHS) 等 $n$ ーアルキ

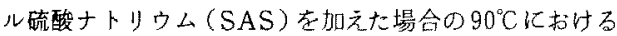
ナイロンに対するオレンジ【の時間一吸着舅等温線を得 た。SHSは例外として，時間一吸着量等温線は， $M_{t}=$ $M_{i}\left(1-e^{-k t}\right)$ にって表わされるてよがわかった。こて で $M_{t}$ および $M_{i}$ は時間 $t$, および平衡に招訬る染料吸着 量， $k$ は造度定数に相当する。SHSを加えた場合， $t=$
}

6分の上ころで吸着量は最大となる。 $M_{i}$ およびM は， SASの添吅濃度が大になるにしたかっって，またナイロン に対する親和力が大きいSAS が共存する墂合の方が小 さくなる。SASが共存する場合の速度定数は，SASが 共存しない場合よりも小であった。SASが共存する場 合のオレンジ』の掘散係数はSTSを除いて，SASが共 存しない場合上りも小であった。STSが共存する場合の オレンジIIの搪散俰数は最大であったととは與味㳭い。 